\title{
Effects of Dust Exposure to Lung Function on Cement Loading Worker
}

\author{
Ezi Dwi Putra, Mursid Raharjo, Nurjazuli
}

\author{
Department of Environmental Health, Faculty of Public Health, Diponegoro University, Indonesia \\ Corresponding author: ezyarwindo@yahoo.co.id
}

\begin{abstract}
Exposure to environmental contaminants in the work area such as dust can cause disruption of lung function of workers. If lung function is disrupted, it certainly can reduce one's health condition which will have an impact on decreasing work productivity. This study aims to analyze the impact of dust exposure on lung function disorders in obese workers and who have smoking habits. This study uses a cross sectional design. The results showed there was a relationship between the level of inhaled dust and obstructive pulmonary function disorders in respondents who had smoking habits ( $p$ value $=0.013)$ and in respondents who had excess BMI $(p$ value $=0.009$ )
\end{abstract}

Keywords - dust exposure, lung function, cement loading worker.

\section{INTRODUCTION}

Development in the industrial sector is also one of the government's commitments to realize the welfare of its citizens. The development should be carried out with the concept of environmentally sound to reduce and prevent the adverse effects of pollution or pollutants produced. Air pollution is a mixture of natural and man-made substances that accumulate in the air (National Institute of Environmental Health Science (NIEHS), 2019). Air pollution is currently considered the most serious environmental health risk in the world by the World Health Organization (WHO). Data from WHO showed that 4.2 million deaths occur each year due to exposure to ambient air pollution. Around $91 \%$ of the world's population lives and works in places where air quality exceeds WHO limits (World Health Organization(WHO), 2018). Pollutants resulting from industrial activities can be in the form of gas and particulates that pose a risk to human health. Pollutants that enter the body through the respiratory system or skin can cause allergic reactions, respiratory disorders, and various acute and chronic diseases such as asthma, chronic obstructive pulmonary disease, pulmonary dysfunction, skin and eye diseases, acute bronchitis, cardiovascular disease, and cancer (Eom et al., 2018).

Lung function tests are useful for diagnosing the cause of pulmonary dysfunction. Many organizations including the National Asthma Education and Prevention Program, the Global Initiative for Chronic Obstructive Lung Disease (GOLD), and the American Thoracic Society (ATS) recommend using standard normal values for pulmonary function examinations. Obstructive pulmonary function disorder if FEV1 / FVC ratio in adults $\geq 70 \%$ (Johnson \& Theurer, 2014).

Data from the Cembureau The European Cement Association in 2017 shows an increase in cement production every year. In 2001 Indonesian cement production was 31.1 million tons and increased to 63 million tons in 2016 (The European Cement Association (Cembureau), 2017). Someone who works in a dusty environment has the risk of breathing in particles that have a bad impact on the respiratory system. The cement processing and management industry is very closely related to the characteristics of a dusty work environment. Cement industry activities that produce air pollutants in the form of dust certainly have a negative impact on workers' health. Exposure to cement dust at the construction site caused various respiratory diseases with impaired lung function. Cement dust particles have a size between 1-100 microns (Colorado Correctional Industries, 2019). Whereas particle size $<100 \mu \mathrm{m}$ is in the inhaled range for humans. Particles $<10 \mu \mathrm{m}$ can enter the lungs and potentially cause problems for human health. Particles $>10$ $\mu \mathrm{m}$ are not inhaled into the lungs but are trapped in the nose.(Thomas, 2013) Chronic exposure to cement dust to workers is known as an important factor in causing respiratory problems (Poornajaf, Kakooei, Hosseini, \& Ferasati, 2010). Research conducted by Poornajaf et al (2010) showed that workers exposed to dust compared to the unexposed group showed a significant decrease in FEV1, FVC, and FEV1 / FVC ( $\mathrm{p}<0.05$ ) (Poornajaf et al., 2010). The purpose of this study was to analyze the impact of dust exposure on impaired lung function in obese workers and smoking habits. 


\section{METHODOLOGY}

This type of research is observational analytic with cross sectional approach. This research was conducted at PT. Karya Citra Tanindang which is a cement distributor company in Bengkulu City. The number of samples in this study were 45 respondents. Sampling is done by nonprobability sampling with purposive judgment sampling technique. Lung function was measured using the Fukuda Sangyo SpiroAnalyzer ST-75 Spirometer. Inhaled dust content was measured using a Personal Dust Sampler.

The normality of the data needs to be known before carrying out further analysis. Test for normality using Shapiro-Wilk. Significance of 2 tailed shows the data are not normally distributed ( $p$ value $<0.05$ ). Correlation test to analyze the relationship of inhaled dust levels with impaired lung function in obese workers using Kendal's Tau. While the correlation test on workers who smoke uses the Pearson correlation test.

\section{RESULT}

The results showed the average level of inhaled dust was $6.46 \mathrm{mg} / \mathrm{m} 3$. The minimum value of inhalation dust is 3.33 and the maximum value of inhalation dust is 10.83 $\mathrm{mg} / \mathrm{m} 3$ (Table 1). The correlation test results showed no relationship between the level of living dust with the ratio of FVC/FVC Pred Ratio ( $p$ value $=0.129$ ) for respondents who have smoking habits. Correlation test results show there is a relationship between the level of inhaled dust with the ratio of FEV1/FVC Ratio ( $p$ value $=0.013$ ) in respondents who have smoking habits. Kendall's Tau correlation coefficient value is -0.273 . The correlation coefficient is negative meaning that if the level of inhaled dust increases, the ratio of FEV1/FVC Ratio decreases. The correlation coefficient value of 0.273 indicates a low level of relationship between the level of inhaled dust and the ratio of FEV1/FVC Ratio (Table 2).

Correlation test results showed no relationship between the level of living dust with the ratio of FVC/FVC Pred Ratio ( $\mathrm{p}$ value $=0.919)$ for respondents who had excess BMI or overweight. Correlation test results show there is a relationship between the level of inhaled dust with the ratio of FEV1/FVC Ratio ( $\mathrm{p}$ value $=0.009$ ) for respondents who have excess BMI. Pearson correlation coefficient value is $-0,807$. The correlation coefficient is negative meaning that if the level of inhaled dust increases, the ratio of FEV1/FVC Ratio decreases in overweight respondents. Correlation coefficient value of 0.807 shows the level of a very strong relationship between the level of inhaled dust with the ratio of FEV1/FVC Ratio in overweight respondents (Table 3 ).
Table 1. Respirable dust level

\begin{tabular}{lc}
\hline Respirable dust level & Value $\left(\mathrm{mg} / \mathrm{m}^{3}\right)$ \\
\hline Mean & 6,46 \\
Minimal & 3,33 \\
Maksimal & 10,83 \\
\hline
\end{tabular}

Table 2. Results of pulmonary function tests (PFT) and Kendall's Tau correlation coefficients for the relation between PFT and dust expossure of smoker workers

\begin{tabular}{lcccc}
\hline & Mean \pm SD & Range & $\mathrm{r}$ & $\mathrm{p}$ \\
\hline FVC/FVC & $76,86 \pm 21,958$ & 23,51 & 0,129 & 0,235 \\
Pred Ratio & & - & & \\
$(\mathrm{n}=45)$ & & 128,07 & & \\
FEV1/FVC & $93,19 \pm 31,778$ & 31,84 & $-0,273$ & 0,013 \\
Ratio & & - & & \\
$(\mathrm{n}=45)$ & & 217,24 & & \\
\hline
\end{tabular}

Table 3. Results of pulmonary function tests (PFT) and Pearson correlation coefficients for the relation between PFT and dust expossure of obese workers

\begin{tabular}{lcccc}
\hline & Mean \pm SD & Range & r & $\mathrm{p}$ \\
\hline FVC/FVCPred & $81,99 \pm 16,847$ & $57,32-$ & - & 0,919 \\
Ratio (n=9) & & 111,67 & 0,040 & \\
FEV1/FVC & $87,84 \pm 18,291$ & $60,80-$ & - & 0,009 \\
Ratio (n=9) & & 117,53 & 0,807 & \\
\hline
\end{tabular}

\section{DISCUSSION}

When smoking occurs a process of burning tobacco and nicotine by removing pollutants of solid particles and gases. Cigarette smoke acts as an oxidant and ciliary activity, and can cause mucous hypertrophy. Smoking can cause changes in the structure and function of the respiratory tract and lung tissue. If the work environment condition of a smoker has a high level of dust concentration, it can cause lung function disorder which is characterized by decreased lung function (VC, FVC, and FEV1).(Wulandari, Tarigan, \& Lubis, 2014) There are 45 respondents who have smoking habits. Correlation test results showed no relationship between the level of living dust with the ratio of FVC/FVC Pred Ratio in respondents who have smoking habits. Correlation test results show there is a relationship between the level of inhaled dust with the ratio of FEV1/FVC Ratio in respondents who have smoking habits. The value of the correlation coefficient Kendall's know is -0.273 . The correlation coefficient is negative meaning that if the level of inhaled dust increases, the ratio of FEV1/FVC Ratio decreases. The correlation coefficient value of 0.273 indicates a low level of relationship between the level of inhaled dust and the ratio of FEV1/FVC Ratio. Dust that is buried in the lungs will cause fibrosis (hardening of the lung tissue), 
which can reduce the vital capacity of the lungs. Environment exposed to dust from cement loading and unloading activities coupled with smoking habits can have a cumulative effect on the onset of lung health problems because cigarette smoke can eliminate cilia feathers in the respiratory tract that function as air filters that enter the nose so that the mechanism of dust removal by lung can be disturbed. (Wulandari et al., 2014)

Fat accumulation can occur in any part of the human body. Excessive accumulation of fat under the diaphragm and on the chest wall can suppress lung damage, resulting in respiratory distress and shortness of breath, even though the sufferer only does light activity.(Wulandari et al., 2014) There were 9 respondents who were overweight or BMI. Correlation test results show there is no relationship between the level of living dust with the ratio of FVC/FVC Pred Ratio in respondents who have excess BMI or overweight. Correlation test results show there is a relationship between the level of inhaled dust with the ratio of FEV1/FVC Ratio in respondents who have excess BMI. Pearson correlation coefficient value is $-0,807$. The correlation coefficient is negative meaning that if the level of inhaled dust increases, the ratio of FEV1/FVC Ratio decreases in overweight respondents. Correlation coefficient value of 0.807 shows the level of a very strong relationship between the level of inhaled dust with the ratio of FEV1/FVC Ratio in overweight respondents. Force vital capacity decreased significantly in obese subjects compared to non-obese subjects.(Wang, Sun, Hsia, Lin, \& Li, 2017)

\section{CONCLUSION}

Based on the results of this study it can be concluded that there is a relationship between the level of inhaled dust with obstructive pulmonary function disorders in respondents who have smoking habits $(\mathrm{p}$ value $=0.013$ ) and in respondents who have excess BMI ( $\mathrm{p}$ value = 0.009).

\section{ACKNOWLEDGEMENTS}

Authors would like to thank the Development and Empowerment of Human Resources of the Ministry of Health of the Republic of Indonesia for funding this research.

\section{REFERENCES}

[1] Colorado Correctional Industries. (2019). Particle size chart. USA: Coloradoci.

[2] Eom, S., Choi, J., Bae, S., Lim, J., Kim, G., Yu, S., ... Kwon, H. (2018). Health effects of environmental pollution in population living near industrial complex areas in Korea. Environmental Health and Toxicology, 33(1), 1-8. https://doi.org/https://doi.org/10.5620/eht.e2018004

[3] Johnson, J. D., \& Theurer, W. M. (2014). A Stepwise Approach to the Interpretation of Pulmonary Function Tests. American Academy of Family Physicians, 89(5), 359-366.

[4] National Institute of Environmental Health Science (NIEHS). (2019). Air Pollution. Retrieved March 22, 2019, from https://www.niehs.nih.gov/health/topics/agents/airpollution/index.cfm

[5] Poornajaf, A., Kakooei, H., Hosseini, M., \& Ferasati, F. (2010). The Effect of Cement Dust on the Lung Function in a Cement Factory, Iran. International Journal of Occupational Hygiene, 2(2), 4-8.

[6] The European Cement Association (Cembureau). (2017). Activity Report Cement Industry 2017. Brussels. Retrieved from https://cembureau.eu/media/1716/activity-report2017.pdf

[7] Thomas, R. J. (2013). Particle size and pathogenicity in the respiratory tract. Virulence, 4(8), 847-858.

[8] Wang, S., Sun, X., Hsia, T., Lin, X., \& Li, M. (2017). The effects of body mass index on spirometry tests among adults in Xi'an, China. Medicine, 96(15), 13-16. https://doi.org/10.1097/MD.0000000000006596

[9] World Health Organization(WHO). (2018). Ambient air pollution. Retrieved April 21, 2019, from https://www.who.int/gho/phe/outdoor_air_pollution/en/

[10] Wulandari, D. A., Tarigan, L., \& Lubis, H. S. (2014). Karakteristik dan Kapasitas Vital Paksa Paru Pekerja Bagian Produksi Aspal Hotmix PT. Sabaritha Perkasa Abadi Tahun 2014. Jurnal Lingkungan Dan Keselamatan Kerja. 